\title{
Density and niche segregation of two armadillo species (Xenarthra: Dasypodidae) in the Vale Natural Reserve, Brazil
}

\author{
Atilla Colombo Ferreguetti ${ }^{\mathrm{a}, *}$, Walfrido M. Tomas ${ }^{\mathrm{b}}$, Helena G. Bergallo ${ }^{\mathrm{a}}$ \\ a Department of Ecology, Rio de Janeiro State University, Rio de Janeiro, Brazil \\ b Wildlife Laboratory, Embrapa Pantanal, Mato Grosso do Sul, Brazil
}

\section{A R T I C L E I N F O}

\section{Article history}

Received 25 May 2015

Accepted 7 October 2015

Handled by Mauro Lucherini

Available online 28 October 2015

\section{Keywords:}

Atlantic Forest

Camera-trap

Distance sampling

Dasypus novemcinctus

Euphractus sexcinctus

\begin{abstract}
A B S T R A C T
We provide the first estimates of density and population size of two sympatric species of armadillos (Euphractus sexcinctus and Dasypus novemcinctus) for the Vale Natural Reserve, evaluating how poaching would be affecting their habitat use (i.e. detectability and occupancy probability) and also describing their activity patterns. Abundance and density were estimated using a distance sampling technique. Occupancy, detectability, and activity patterns were assessed using camera-trapping during a one-year period. Estimated population densities were 0.06 individuals per hectare (ind/ha) and 0.05 ind/ha for $D$. novemcinctus and E. sexcinctus, respectively. Occupancy probability of both species was affected by the distance to forest edge. D. novemcinctus showed a positive relationship with increasing distance from the edge, whereas E. sexcinctus showed an opposite relationship. D. novemcinctus also showed higher occupancy rates in sites closer to a water resource. Additionally, occupancy and detectability of both species were negatively affected by historical poaching intensity in the reserve. Activity patterns varied between species, with $D$. novemcinctus being mostly nocturnal and E. sexcinctus being diurnal. We conclude that despite the two armadillo species sharing several niche dimensions, they showed spatial and temporal segregation. These differences may be an adaptation to reduce interspecific competition but may also be affected by the need to avoid poaching pressures. This study contributes to increase the knowledge and conservation of these two little-studied species.
\end{abstract}

(C) 2015 Deutsche Gesellschaft für Säugetierkunde. Published by Elsevier GmbH. All rights reserved.

\section{Introduction}

The main cause of mammalian population declines in the Atlantic Forest of Brazil and worldwide has been the loss and fragmentation of habitats (Mace et al. 2000). Poaching is the second most important cause of reduction of natural populations and local extinctions of threatened animals (Rosser and Mainka 2002), especially mammals (Mace et al. 2000), in the world. The expected immediate effect of poaching pressure on mammal communities is the decline of populations of hunted species, which negatively affects their abundance and overall biomass (Redford 1992; Bodmer and Penn Junior 1997; Peres 2000). Redford (1992) estimated in Amazon forest an $80 \%$ decrease of non-primate mammal densities in moderately hunted areas when compared to areas with no record of poaching. In addition to direct impacts on mammal populations, there are the indirect effects on ecological processes. Many of the most widely consumed species have important roles

\footnotetext{
* Corresponding author.

E-mail address: atilla.ferreguetti@gmail.com (A.C. Ferreguetti).
}

in the maintenance of diversity mechanisms and landscape structure, such as herbivory, seed dispersal and predation (Dirzo and Miranda 1990; Redford 1992). Moreover, the poached species are generally the prey of large predators, which may indirectly reduce the abundance of these predator species (Redford 1992).

Members of the Dasypodidae are the most widely distributed species within the Magnaorder Xenarthra, occurring from the United States to Argentina (Emmons 1990; Eisenberg and Redford 1999; Nowak 1999). The Atlantic Forest of Brazil potentially harbors six species of armadillos: Cabassous unicinctus, C. tatouay, Dasypus novemcinctus (common long-nosed armadillo), D. septemcinctus, Euphractus sexcinctus (six-banded armadillo), and Priodontes maximus (Anacleto et al. 2006; Wetzel et al. 2007; Paglia et al. 2012). All of these species are impacted by poaching pressures (Urquiza-Haas et al. 2011; Santos-Fita et al. 2012; Souza and Alves 2014).D. novemcinctus and E. sexcinctus occupy the largest geographic distributions within the family and occur in overlapping regions throughout their distribution in Brazil, except in the Amazon region (Eisenberg and Redford 1999; Abba et al. 2014; Loughry et al. 2014). These two species are also heavily poached across their range (Chiarello 2000; Peres 2000). 
Armadillos are usually nocturnal and can be difficult to observe and capture, which has made researching their ecological roles and impacts difficult. Despite forming a relatively large group of mammalian species, including several endangered species, the majority of armadillo research regarding natural ecology and behavior is minimal (McDonough and Loughry 2008). Currently, most of the knowledge on the ecology of armadillos comes from studies conducted in captivity: less than $20 \%$ of the armadillo studies were based on field work conducted on wild populations (Superina et al. 2014; Loughry et al. 2015). The Neotropical region is lacking studies regarding these species, including information on the exact distribution of species (McDonough and Loughry 2008; Superina et al. 2014; Loughry et al. 2015).

Assuming that organisms are not equally distributed in space and time, biological explanations for the spatial and temporal variations in habitat selection are essential to understand the patterns of distribution, structure, ecological processes, and functions in ecosystems (Morris 1987). Habitat selection studies are also important in the conservation context because they provide information on the environmental requirements of a species, which results in expanded information regarding their ecology, spatial distribution, and population dynamics.

To contribute to the understanding of ecological patterns in Neotropical armadillos, as well as the conservation of their populations, this study aimed to provide the first estimates of density of two species of armadillos (E. sexcinctus and D. novemcinctus) for the Vale Natural Reserve (VNR), located in the Atlantic Forest of Brazil. Since both species are hunted, we also evaluated how poaching affects spatial and temporal habitat use by examining the effect of poaching on the detectability and occupancy probability of each species. We tested the hypothesis that occupancy probability and detectability would be higher in areas with lower poaching influence. Additionally, we also expected that the two species would have similar population densities in the reserve, since both species are hunted and share several physiologic characteristics (Eisenberg and Redford 1999). Finally, we tested the hypothesis that since the two species share a similar diet and others niche components, they should present distinct patterns in space (habitat use) and/or time (activity period) to avoid competition. To check if interspecific habitat segregation occurred, we tested their responses to seven covariates that were selected on the base of previous information on these species according to Eisenberg and Redford (1999) and McDonough and Loughry (2008).

\section{Material and methods}

\section{Study area}

The study was conducted in the Vale Natural Reserve (VNR), a protected area of 23,500 ha belonging to the Vale Company. The reserve is located in the neighboring municipalities of Linhares and Jaguare $\left(19^{\circ} 06^{\prime}-19^{\circ} 18^{\prime} \mathrm{S}\right.$ and $\left.39^{\circ} 45^{\prime}-40^{\circ} 19^{\prime} \mathrm{W}\right)$, in northeastern Espírito Santo, Brazil (Fig. 1).

VNR is composed of one main block of forest (approximately $98.1 \%$ of the total area), and a much smaller fragment, known as Biribas Reserve, to the southwest of the main block.

According to the Vegetation Map of Brazil (IBGE 1993), VNR is covered by dense forest, composed by a mosaic of habitats with four main vegetation types (adapted from Jesus 1987; Peixoto and Gentry 1990): coastal plain forest ("tabuleiro" forest), riparian forest, "mussununga" forest, and natural grassland. The evergreen tabuleiro forest has two or more upper strata, high densities of lianas and epiphytes, and covers approximately $68 \%$ of the total area of the reserve. The riparian forest, which covers some $4 \%$ of the reserve, is a mixed type of vegetation associated with streams, characterized by widely spaced trees and a predominance of palms. The mussununga forest (covering approximately $8 \%$ of VNR) is a type of woody vegetation growing on sandy soils, physiognomically similar to the tabuleiro forest at an early or intermediate stage of regeneration. The natural grasslands occur as enclaves within the forest, which were the sites of ponds in the geological past and cover around $6 \%$ of the area of the reserve. In addition to these formations, approximately $8 \%$ of the reserve is covered by wetlands (swamps) and streams (Fig. 1).

\section{Line-transect surveys}

To estimate density and abundance of $D$. novemcinctus and $E$. sexcinctus, we established four $5 \mathrm{~km}$-long line transects stratified by habitat type in our study area (Karanth et al. 2004), using the RAPELD protocol (Magnusson et al. 2005). Transects were separated from one other by a minimum of $4 \mathrm{~km}$.

During a 13-month period (April 2013 to May 2014), transects were surveyed using distance sampling techniques (Buckland et al. 2001 ) (Fig. 1). Each transect was surveyed twice a month by a single observer starting at sunrise (between 05:30 and 06:30 h). The observer waited three hours before starting the afternoon survey, between 13:00 and 14:00 h. The observer walked transects at a speed of approximately $1 \mathrm{~km} / \mathrm{h}$. For each sighting we recorded the species and the perpendicular distance of the animal from the transect line (measured using measuring tape), the distance walked from the initial point, date, time of day, and the transect number.

\section{Camera-trapping}

To model the occupancy probability of each species, as well as to document their respective activity patterns, we selected 39 sampling sites using a systematic random design stratified by vegetation type to ensure that all four of the principal vegetation types found in the VNR were represented (i.e. tabuleiro forest, riparian forest, mussununga forest, and natural grassland; Fig. 1).

We placed a grid over a digital map of the reserve and identified the sampling sites by randomly selecting grid cells. Then, in the center of each selected grid cell, we looked for locations with armadillo tracks and following and deployed camera traps at those locations. This approach resulted in a relatively even distribution of sites within the VNR. The sites were separated from one another by a distance of more than $1 \mathrm{~km}$ and to ensure temporal independence we excluded records separated by less than $24 \mathrm{~h}$ (Powell et al. 2008). We did not use baits to attract the armadillos. At each site, we installed one passive infrared Bushnell ${ }^{\circledR}$ camera trap, approximately $40-50 \mathrm{~cm}$ above the ground. All cameras were checked every 20-25 days to replace depleted batteries. Traps were programmed to operate for $24 \mathrm{~h} /$ day. We collected presence/absence records between May 2013 and June 2014.

\section{Covariates}

We used the same seven covariates to model occupancy probability for the two armadillo species. These were the distance to forest edge (i.e. tabuleiro forest, riparian forest, mussununga forest; “dist_edge"), density of trees with a Diameter at Breast Height of more than $50 \mathrm{~cm}$ (dens_trees), liana density (dens_lian), distance to water (dist_water), understory cover (und_cov), and distance to the main road (dist_main_road). A priori, these covariates were selected to represent key habitat features (dens_trees, und_cov, dens_lian, and dist_water) or elements possibly avoided by one or both species (dist_main_road; dist_edge). The potential effect of poaching on detectability and occupancy probability was also analyzed.

At each sampling point, we established four plots $(30 \mathrm{~m} \times 50 \mathrm{~m})$ arranged by the cardinal compass points (north, south, east, 


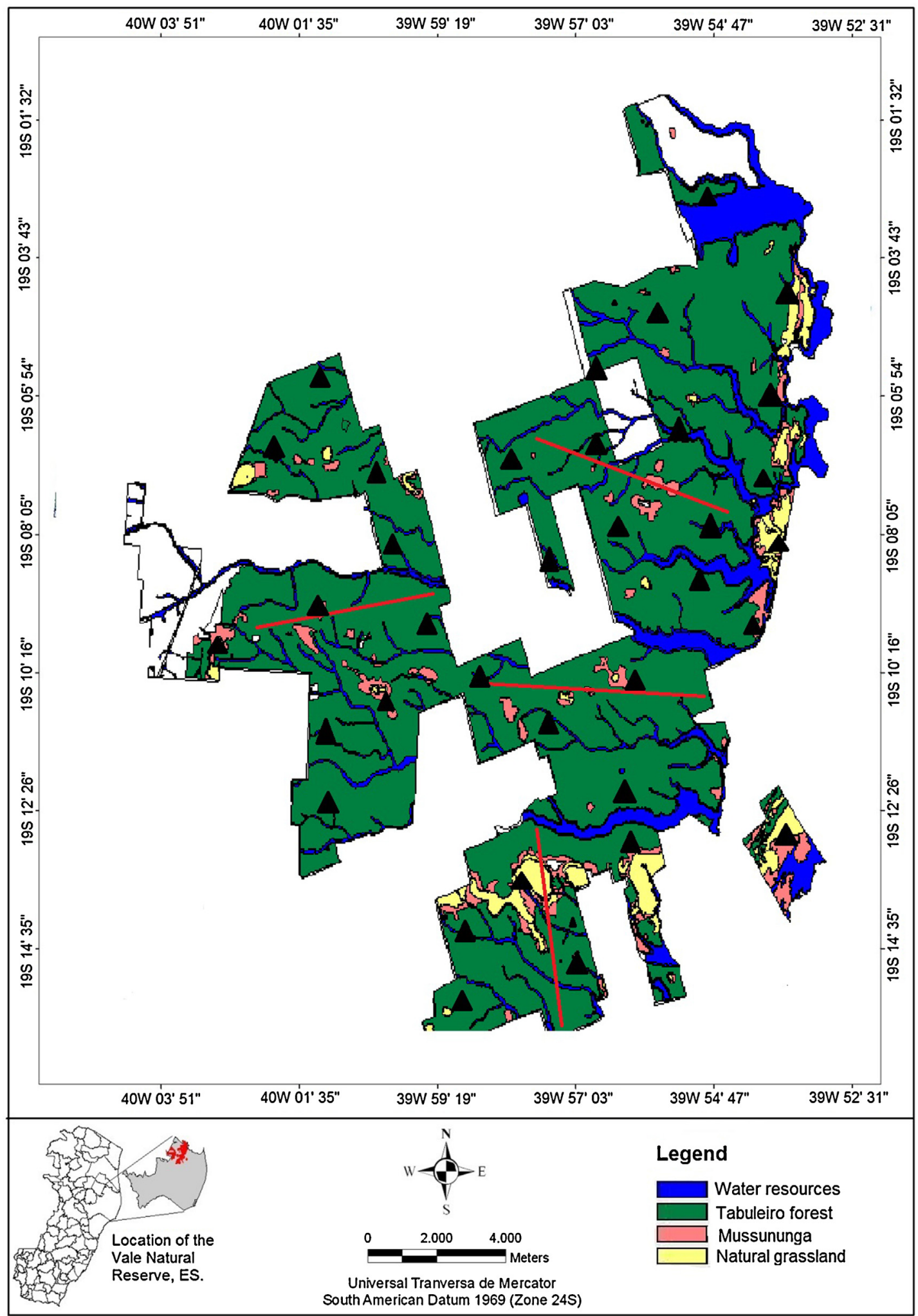

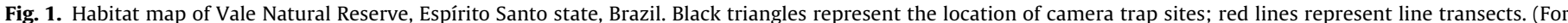
interpretation of the references to color in this figure legend, the reader is referred to the web version of the article.)

and west). In each plot, we measured the Diameter at Breast Height (DBH) of each tree and counted the number of large trees $(\mathrm{DBH}>50 \mathrm{~cm})$. Understory cover and liana density were measured along the central (longitudinal) line of each plot, considering $5 \mathrm{~m}$ on each side of the line. The liana density was calculated on the number of stems rooted within each $10 \mathrm{~m} \times 50 \mathrm{~m}$ transect. Understory cover was measured every $10 \mathrm{~m}$ using a $2 \mathrm{~m} \times 0.5 \mathrm{~m}$ sighting frame (each $0.5 \mathrm{~m}^{2}$ portion representing $25 \%$ visibility). Understory cover within each transect was estimated by the mean visibility of the sighting frame at five sampled points. 
Distances to forest edge, water distance, and main road were quantified for each of the 39 sampling sites using the ArcGIS software (ESRI*ArcMap 10.1).

Poaching intensity within the study area was estimated using the georeferenced database of a 10 -year period in which poaching events were recorded by the reserve's security guards (source: Vale Natural Reserve). The density of poaching records per $\mathrm{km}^{2}$ was calculated for each grid cell in which a camera trap had been installed by dividing the number of records by the grid cell area and used as a proxy for poaching intensity.

\section{Data analysis}

Density and population size were estimated using the total number of individuals observed along each trail through the program DISTANCE 6.2 (Buckland et al. 2001). To analyze distance sampling data, the probability of detection in the center of the transect has to be 1 . In our study this assumption could not be met because armadillos cannot be detected inside burrows. DISTANCE uses the perpendicular distances to the observed animals to estimate effective strip width (ESW) in the study area and model the detection function that best suits the probability of detection of an animal at a given distance (Buckland et al. 2001; Laake et al. 1994). The best detection model is selected by the Akaike Information Criterion (AIC; Akaike 1973). Burnham and Anderson (2002) recommend using the AIC to select models only when the number of observations is greater than or equal to 40 to produce accurate estimates.

We estimated detection probabilities by sampling each site on multiple occasions, using 5-day intervals (occasions) based on MacKenzie and Royle (2005). We concluded that this interval was sufficient to construct a reliable detection history. We estimated site occupancy $(\Psi)$ and detection probability $(p)$ for each species, with three possible outcomes: (1) the site was occupied and the species was detected $(\Psi \times p)$; (2) the species was present but not detected $(\Psi \times[1-p])$, and (3) the species was not present and therefore was not detected $(1-\Psi)$.

The occupancy probability was the parameter projected by a maximum likelihood estimation of the proportion of sites occupied $(\Psi)$ during the sample period. We verified that occupancy was closed (i.e., did not change) for both species using a singleseason model. This exercise indicated that the occupancy status for each species was constant throughout the study, allowing for closed occupancy models to be used (MacKenzie et al. 2006).

In our occupancy analysis, we considered each species separately in an attempt to identify divergences in habitat preferences. We constructed a set of 10 candidate models selected by a priori hypotheses based on three different approaches: (1) considering occupancy probability and detectability as constant across all sites for both species, (2) considering the variation in occupancy as a function of habitat covariates, and (3) considering the variation in occupancy probability and detectability as a function of poaching density.

Occupancy modeling was run in the PRESENCE 8.3 software (MacKenzie and Royle 2005) with 2000 bootstraps to assess the adjustment fit $(p)$ and the over-dispersion parameter $(\hat{c})$. In our assessment of occupancy closure and the factors that influenced occupancy and detection, we ranked all models according to AIC (Akaike 1973). All models with a deltaAIC value of less than 2 were considered to be equivalent. We estimated the mean model from the entire set of models by using the weight (AICwt) for each one, which corresponds to the amount of evidence in favor of a given model. This mean model was used to test our hypotheses.

The circadian cycle of each species was defined based on the timing of independent records obtained from the camera traps. To avoid pseudoreplication, records were only considered to be

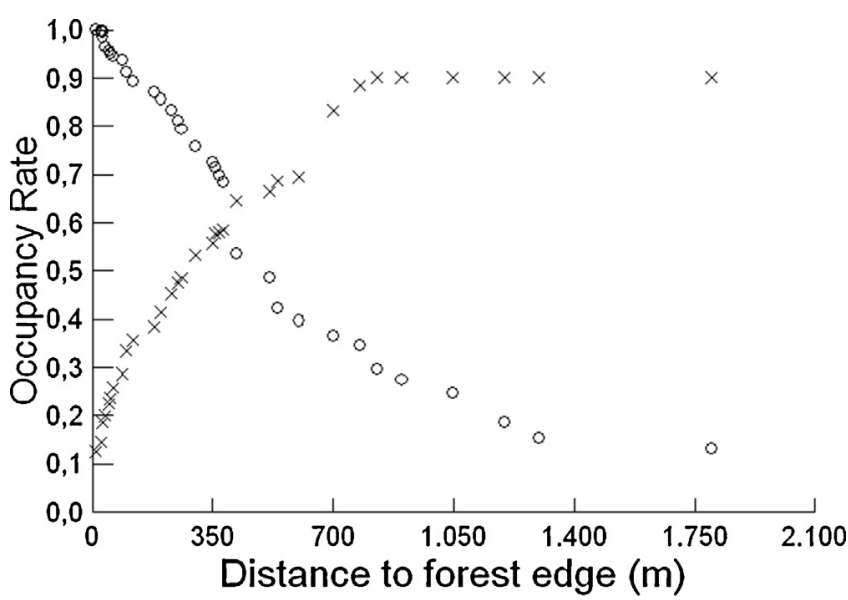

Fig. 2. Variation of occupancy probability by D. novemcinctus (cross symbol) and $E$. sexcinctus (circle symbol) as a function of the distance from forest edge in the Vale Natural Reserve, Espírito Santo state, Brazil, estimated by camera-trapping from May 2013 to June 2014.

independent when separated by an interval of $24 \mathrm{~h}$. Analyses were conducted in the "Circular" package in R(R Development Core Team 2008) with associated analytic packages. Circular summaries (Lund and Agostinelli 2007) were used to determine the mean overall timing of the activity of each species as recorded by the camera traps. A resampling approach was used to derive unbiased estimates of the 95\% confidence intervals (95\% CIs), whereby the circular mean from a random sample of 100 data points for each species was calculated 10,000 times with replacement to generate reliable estimates.

\section{Results}

\section{Density and population size}

A total of $980 \mathrm{~km}$ of transects (196 samples) were surveyed in this study for both $E$. sexcinctus and $D$. novemcintus. Throughout the surveys, E. sexcinctus and D. novemcinctus were sighted 74 times and 76 times, respectively. Observation for each species were obtained from 0 to $24 \mathrm{~m}$ from the transect line.

Estimated density for $D$. novemcinctus was $0.06 \pm$ 0.02 individuals/ha and the estimated population size was $1456 \pm 242$ individuals with an effective strip width (ESW) of $3.45 \pm 0.42 \mathrm{~m}$. The best fit model for our data was Negative Exponential with cosine adjustment. Estimated density for $E$. sexcinctus was $0.05 \pm 0.01$ individuals/ha and the estimated population size was $1175 \pm 148$ individuals with an ESW of $7.50 \pm 0.81 \mathrm{~m}$. The model which best fitted our data was Half-normal with cosine adjustment.

\section{Occupancy and detectability models}

A total effort of 7020 trap-days produced 827 independent events of $D$. novemcinctus, and 324 of $E$. sexcinctus.

D. novemcinctus was observed in 25 of the 39 sites, which resulted in a naïve occupancy of 0.64 and a detectability of 0.41 and E. sexcinctus was observed in 30 of the 39 sites, which resulted in a naïve occupancy of 0.79 and a detectability of 0.35 . From the ten occupancy models produced for each species (Table 1), $D$. novemcinctus occupancy was best described by two covariates: (1) distance to forest edge, which presented a positive relationship. In sites located at more than $750 \mathrm{~m}$ to the forest edge, occupancy was high ( $\Psi=0.8 \pm 0.08$ ), reaching a maximum of 0.9 . Occupancy probability was reduced to approximately $18 \%$ at distances smaller than 250 meters (Fig. 2); (2) distance to water. Occupancy probability 
Table 1

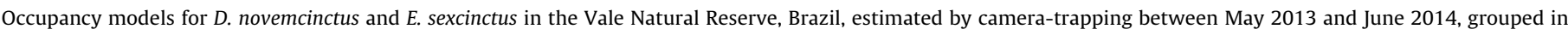

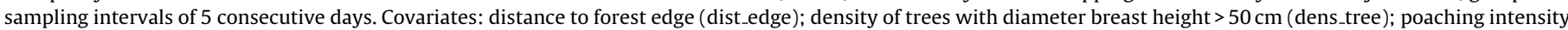

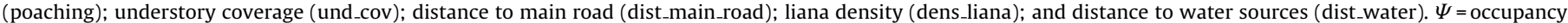
$p=$ detectability, $\mathrm{AIC} w=$ Akaike weight, $\hat{z}=$ model fit, $\hat{c}=$ dispersion parameter.

\begin{tabular}{|c|c|c|c|c|c|}
\hline Model & AIC & AICwt & $\mathrm{n}^{\circ}$ parameters & $\hat{z}$ & $\hat{c}$ \\
\hline \multicolumn{6}{|l|}{ Dasypus novemcinctus Linnaeus, 1758} \\
\hline $\boldsymbol{\Psi}$ (dist_edge;dist_water; poaching);p(poaching) & 952.18 & 0.88 & 6 & 0.19 & 1.16 \\
\hline$\Psi$ (dist_edge);p(poaching) & 942.36 & 0.08 & 4 & 0.19 & 1.23 \\
\hline$\Psi$ (dist_water);p(.) & 941.26 & 0.2 & 3 & 0.18 & 1.24 \\
\hline$\Psi(.) ; \mathbf{p}($ poaching $)$ & 937.36 & 0.05 & 3 & 0.18 & 1.22 \\
\hline$\Psi(.) ; p()$. & 936.45 & 0.02 & 2 & 0.21 & 1.25 \\
\hline $\boldsymbol{\Psi}$ (dens_tree); $\mathbf{p}()$. & 932.12 & 0.01 & 3 & 0.22 & 1.25 \\
\hline $\boldsymbol{\Psi}$ (dist_water;poaching); $\mathbf{p}()$. & 932.05 & 0.001 & 4 & 0.18 & 1.24 \\
\hline $\boldsymbol{\Psi}$ (dens_tree);p(poaching) & 930.36 & 0.001 & 4 & 0.18 & 1.22 \\
\hline $\boldsymbol{\Psi}$ (dens_liana;poaching); $\mathbf{p}()$. & 929.45 & 0.001 & 4 & 0.21 & 1.25 \\
\hline$\Psi$ (und_cov);p(poaching) & 922.08 & 0.001 & 4 & 0.22 & 1.25 \\
\hline \multicolumn{6}{|l|}{ Euphractus sexcinctus (Linnaeus 1758) } \\
\hline $\boldsymbol{\Psi}$ (dist_edge; poaching); $\mathbf{p}$ (poaching) & 1106.52 & 0.72 & 5 & 0.20 & 1.19 \\
\hline $\boldsymbol{\Psi}$ (dist_edge); $\mathbf{p}()$. & 1105.20 & 0.18 & 3 & 0.23 & 1.24 \\
\hline$\Psi(.) ; \mathbf{p}$ (poaching) & 1098.32 & 0.04 & 3 & 0.22 & 1.25 \\
\hline$\Psi(.) ; \mathrm{p}()$. & 1096.23 & 0.02 & 2 & 0.21 & 1.25 \\
\hline $\boldsymbol{\Psi}$ (dens_tree);p(.) & 1092.58 & 0.01 & 3 & 0.22 & 1.24 \\
\hline $\boldsymbol{\Psi}$ (dist_water);p(.) & 1092.46 & 0.005 & 3 & 0.21 & 1.24 \\
\hline $\boldsymbol{\Psi}$ (und_cov);p(poaching) & 1090.25 & 0.005 & 4 & 0.22 & 1.25 \\
\hline $\boldsymbol{\Psi}$ (dens_liana;poaching); $\mathbf{p}()$. & 1089.58 & 0.003 & 4 & 0.21 & 1.25 \\
\hline $\boldsymbol{\Psi}$ (dens_tree);p(poaching) & 1088.12 & 0.003 & 4 & 0.22 & 1.24 \\
\hline$\Psi$ (dist_water);p(poaching) & 1087.46 & 0.003 & 4 & 0.21 & 1.24 \\
\hline
\end{tabular}

ranged from $76 \%$ to $47 \%$ in sites located $3600 \mathrm{~m}$ to the closest water source (Fig. 3). Additionally, occupancy probability and detectability of $D$. novemcinctus were both negatively affected by poaching intensity. The higher the poaching, the lower the occupancy and detectability of both species (Fig. 4). Occupancy ranged from $\Psi=0.9$ to 0.42 (Fig. 4A) and detection probability ranged from $p=0.94$ to 0.56 (Fig. 4B). For E. sexcinctus, occupancy was best described by the distance to forest edge. Contrary to $D$. novemcinctus the relationship with forest edge distance was negative, with a high rate of decrease with increasing distance, and $\Psi$ ranged from 1.0 to 0.18 (Fig. 2). Occupancy probability and detectability were also affected negatively by poaching intensity (Fig. 4). Occupancy probability ranged

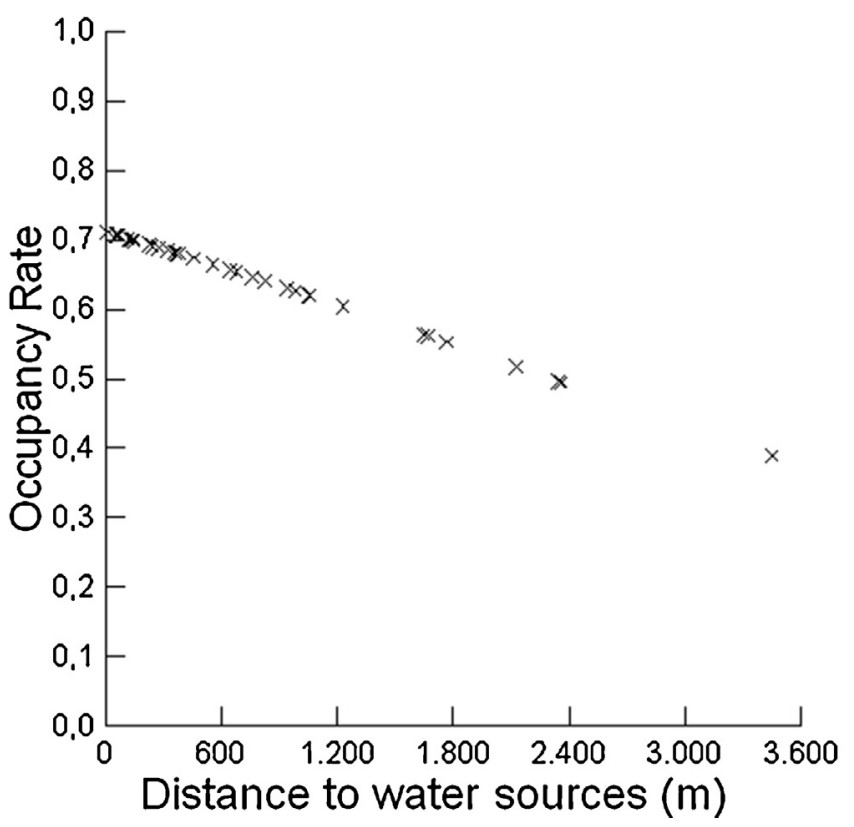

Fig. 3. Relationship between occupancy probability by $D$. novemcintus and the distance from water sources in the Vale Natural Reserve, Espírito Santo state, Brazil, estimated by camera-trapping from May 2013 to June 2014. from $\Psi=0.88$ to 0.37 (Fig. 4 A) and detectability from $p=0.85$ to 0.5 (Fig. 4B).

\section{Activity patterns}

We found a difference in the activity patterns between the species (Fig. 5). D. novemcinctus showed two major peaks, one in the late afternoon (17:00 h, ranging from 15:00 to 21:00 h), and one in the late night $(02: 00 \mathrm{~h}$, ranging from 01:00 to 03:00 h). E. sexcinctus showed two peaks of activity, one peak in the late morning (10:00 h, ranging from 09:00 to $11: 00 \mathrm{~h}$ ), and one peak in the afternoon $(14: 00 \mathrm{~h}$, ranging from 13:00 to $14: 00 \mathrm{~h})$. The species showed an overlap in their activity patterns between 15:00 and 16:00 h.

\section{Discussion}

This is one of the first studies estimating population abundances and reporting information on habitat use and activity patterns for two sympatric species of Dasypodidae, Our estimation of density had a coefficient of variation below $20 \%$ for both armadillo species, which corresponds to the maximum recommended value for an accurate estimate (Buckland et al. 2001). However a key assumption not met in our study was that all individuals occurring on the transect line are detected. This could result in underestimated values of density and population size. In addition, our densities for $D$. novemcinctus may also be underestimated due to the time of the day we selected for the line-transect counts, which covered only a portion of the species activity period found for the VNR area. Nevertheless, we suggest that the estimates presented here could be used as indicators of the population status of these two species. Densities appeared to be low for both species, which was expected because $D$. novemcintus and $E$. sexcinctus are heavily hunted in the area (Chiarello 2000; Peres 2000; Sanches 2001; Aguiar 2004), armadillos are frequent victims of roadkills (Viera 1996; Fischer 1997), and also because they are potential jaguar (Panthera onca) prey in the study area (Srbek-Araujo 2013). Low density estimates could also be related to biological traits typical of the Dasypodidae, such as lower reproductive rates, metabolism and body temperature, as well as to a diet based on low-energy food resources (e.g. ants and/or termites) (Redford and Wetzel 1985; Nowak 1999). 

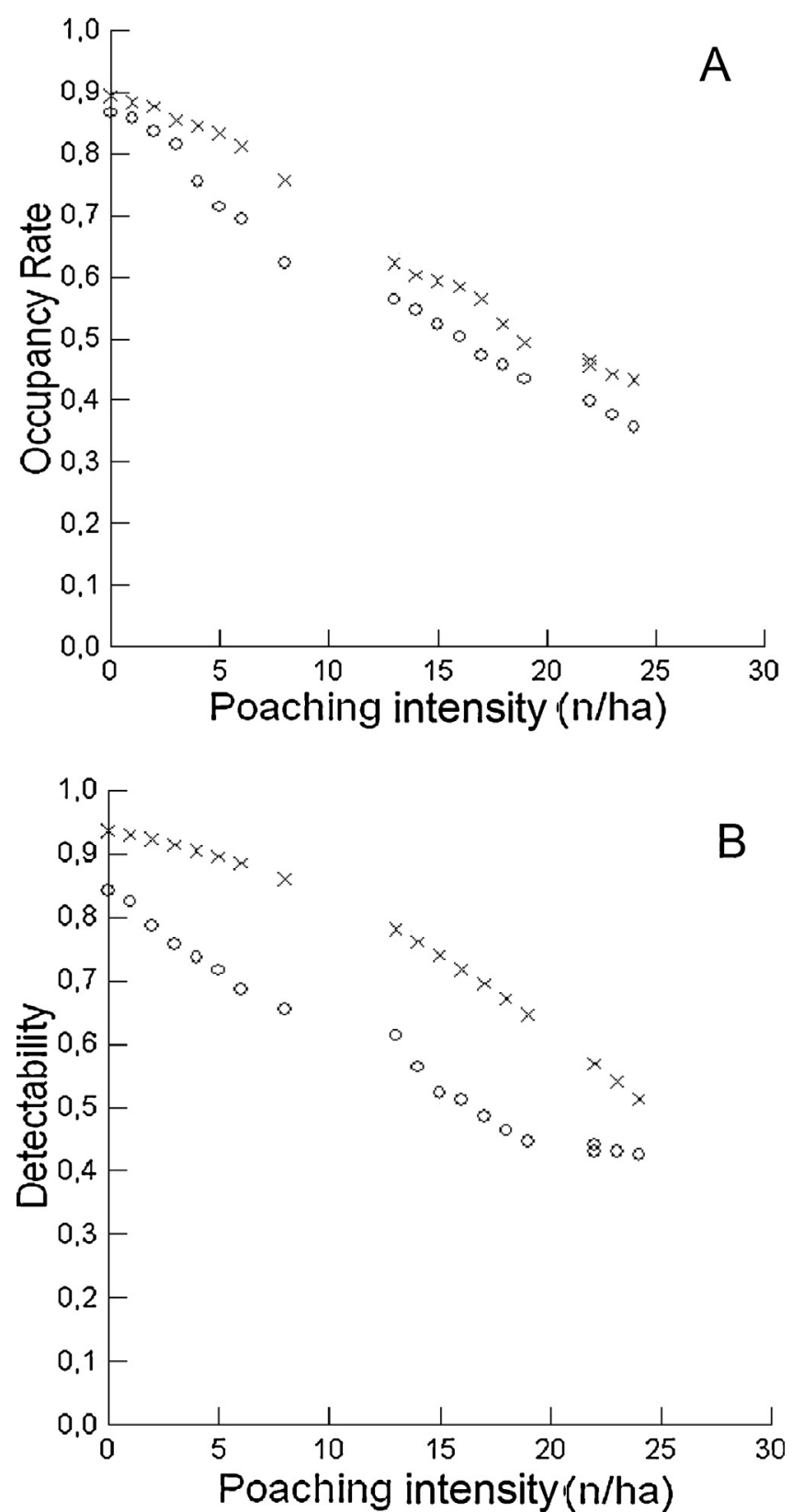

Fig. 4. (A) Variations of occupancy probabilities as a function of poaching intensity for D. novemcinctus (cross symbol) and E. sexcinctus (circle symbol); (B) relationship between detectability and poaching intensity for $D$. novemcinctus (cross symbol) and E. sexcinctus (circle symbol). For both graphs data were estimated by cameratrapping in the VNR, Espírito Santo state, Brazil from May 2013 to June 2014.

However, armadillos can also reach very high population densities as reported by Loughry and McDonough (2013).

$D$. novemcintus showed a $24 \%$ greater abundance than $E$. sexcinctus in our study. This difference in abundance may be related to the preference that we found for E. sexcinctus to use open habitats (also reported by McBee and Baker 1982; Encarnação 1987). The fact that about of $78 \%$ of VNR is covered by forest could have resulted in a lower abundance for this species.

We found that $D$. novemcinctus avoided the forest edge, presenting higher occupancy rates inside the forest. Despite its flexible habitat preference, which comprises both open and forested areas, this species appear to have a more generalized preference for more complex habitats such as riparian and climax forests (McDonough et al. 2000; Bonato 2002; Anacleto and Diniz-Filho 2008). Tabarelli

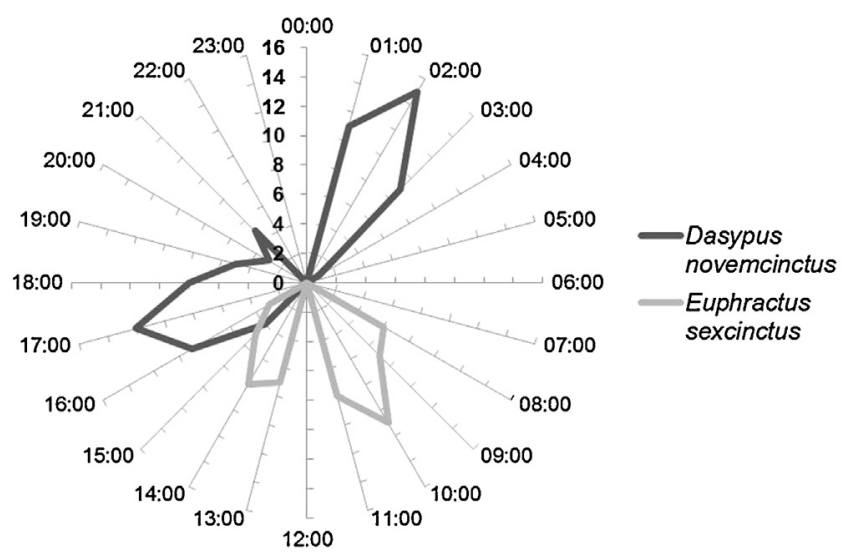

Fig. 5. Activity patterns of $D$. novemcintus and E. sexcinctus in the Vale Natural Reserve, Espirito Santo state, Brazil, estimated by camera-trapping from May 2013 to June 2014.

et al. (1999) demonstrate that the abrupt creation of clearings in forest environments may cause changes in micro-climate conditions, thus promoting the establishment of non-forest species, especially those resistant to sunstroke (i.e. bamboos, lianas and vines). This process is known as the edge effect, which forest species tend to avoid (e.g. Mazama americana, Ferreguetti et al. 2015). Besides the forest edge distance, occupancy probability was affected by the distance to water sources, which is not surprising because $D$. novemcinctus appears to need direct access to fresh water to survive (Loughry and McDonough 2013) and may take advantage of the availability of food resources in areas closest to water (McBee and Baker 1982). On the other hand, E. sexcinctus appears to be more common in open areas with scattered trees and bushes (Redford and Wetzel 1985; Nowak 1999), although Redford and Wetzel (1985) also described the presence of this species at the forest edges. In the Serra da Canastra National Park - Minas Gerais, Brazil, E. sexcinctus used grassland and savannah grasslands, and no individuals have been recorded in gallery forests (Carter and Encarnação 1983; Encarnação 1987). In Pre-Maranhense Amazon, E. sexcinctus are known to use the primary and secondary forests edges and the interior of the non-flooded secondary forests (Silva Junior et al. 2001). These results seem to be in agreement with the negative influence of the forest edge distance on the occupancy probability estimated in our study.

We found that detectability was lower in areas with greater poaching frequency and this suggests that both armadillo species are avoiding them, due to the fact that they are known to be among the most preferred and huntable species in the Neotropics (Schaller 1983; Redford 1985; Hill et al. 1997; Cullen et al. 2000; Ojeda et al. 2002). We also found that sites with a higher poaching intensity had lower occupancy probabilities for both armadillo species. This negative relationship with poaching could represent a reduction in armadillo populations since occupancy could be used as a proxy for species abundance (MacKenzie et al. 2006). Poaching is a factor influencing armadillo populations in Neotropical regions, often with strong impacts (Peres 1990; Bodmer et al. 1994; Glanz 1996; Cullen et al. 2000) and can be a common and difficult habit to change in countries such as Brazil, where surveillance and environmental awareness are still insufficient. In agreement with previous studies that reported that poaching is a conservation issue in VNR (Chiarello 2000; Ferreguetti et al. 2015), we conclude that it is essential to improve surveillance in the reserve. VNR lies within the Sooretama Biological Reserve, forming one of the largest blocks of remaining native vegetation areas within the state of Espírito Santo, and also one of the largest blocks of Tabuleiro Forest left in the Atlantic Forest. Thus, the preservation of wildlife populations 
within VNR is strictly associated to the conservation of the entire block.

The activity pattern that we found for D. novemcinctus was similar to other populations, such as those in North America (Loughry and McDonough 1997). On the other hand, the later peak we found for the VNR population was described in a Brazilian population (Loughry and McDonough 1998). Conversely, our findings confirmed that $E$. sexcinctus has a primarily diurnal activity pattern (Redford and Wetzel 1985). In the Pantanal, Schaller (1983) found a higher activity pattern of E. sexcintus between 12:00 and 15:00 h, which is during the hottest hours of the day. In Bolivia, activity was also recorded between 12:00 and 15:00 h (Cuéllar and Noss 2004), whereas in other regions, the peaks of activity were similar to those recorded for VNR (Hass et al. 2003; Trolle 2003).

As $D$. novemcinctus and $E$. sexcinctus have very similar food habits (McBee and Baker 1982; Redford and Wetzel 1985; Gardner 2007), the spatial and temporal niche segregation that we recorded between the species may contribute significantly to a reduction in interspecific competition (Schoener 1974) and thus favor their long-term coexistence (Begon et al. 2006).

\section{Acknowledgements}

We thank Vale Natural Reserve for the support in the research. We would like to thank the anonymous reviewers of Mammalian Biology for their suggestions to previous versions of this paper. We thank B. Labumbard for the review of the English form. AFC thanks Coordenacão de Aperfeiçoamento de Pessoal de Nível Superior (CAPES) for the scholarship received. HGB thanks FAPERJ (E26/103.016/2011, E26/201.267/2014), Prociência/UERJ and CNPq (457458/2012-7, 307715/2009-4) for the research and productivity grants. This study is part of the Research Program in Biodiversity (PPBio MA). Databases are maintained with support from PPBio MA (CNPq - 457458/2012-7) and FAPERJ (E-26/111.394/2012).

\section{References}

Abba, A.M., Lima, E., Superina, M., 2014. Euphractus sexcinctus. The IUCN Red List of Threatened Species. Version 2014.3, www.iucnredlist.org (accessed 14.04.15).

Aguiar, J.M. 2004. Species summaries and species discussions In: Fonseca, G., Aguiar, J., Rylands, A., Paglia, A., Chiarello, A., Sechrest, W. (Orgs.). The 2004 Edentate species assessment workshop. Edentata 6, 3-26.

Akaike, H., 1973. Information theory and an extension of the maximum likelihood principle. In: Pretov, B.N., Csaki, F. (Eds.), Second International Symposium on Information Theory. Academiai Kiado, Budapest, pp. 267-281

Anacleto, T.C.S., Diniz, J.A.F., Vital, M.V.C., 2006. Estimating potential geographic ranges of armadillos (Xenarthra, Dasypodidae) in Brazil under niche-based models. Mammalia 70, 202-213.

Anacleto, T.C.S., Diniz-Filho, J.A.F., 2008. Efeitos da alteração antrópica do Cerrado sobre a comunidade de tatus (Mammalia, Cingulata, Dasypodidae). In: Reis, N.R., Peracchi, A.L., Santos, G.A.S.D. (Orgs.). Ecologia de Mamíferos. Technical books Editora, Londrina, pp. 55-67.

Begon, M., Towsend, C.R., Harper,J.L., 2006. Ecology: From Individuals to Ecosystems. Blackwell Publishing, Oxford.

Bodmer, R.E., Fang, T.G., Moya, L., Gill, R., 1994. Managing wildlife to conserve Amazonian rainforest: population biology and economic considerations of game hunting. Biol. Conserv. 67, 1-7.

Bodmer, R.E., Penn Junior, J.W., 1997. Manejo da vida silvestre em comunidades na amazônia. In: Bodmer, E.R., Valladares-Pádua, C. (Org.). Manejo e Conservação de vida silvestre no Brasil. CNPq/Sociedade Civil Mamirauá, Brasília/Belém, pp. 56-67.

Bonato, V., (dissertation) 2002. Ecologia e história natural de tatus no Cerrado de Itirapina, São Paulo. Campinas State University, Campinas, Brazil.

Buckland, S.T., Anderson, D.R., Burnham, K.P., Laake, J.L., Borchers, D.L., Thomas, L, 2001. Introduction to Distance Sampling: Estimating Abundance of Biological Populations. Oxford University Press, Oxford.

Burnham, K.P., Anderson, D.R., 2002. Model Selection and Multimodel Inference: A Practical Information and Theoretic Approach, 2nd ed. Springer

Carter, T.S., Encarnação, C., 1983. Characteristics and use of burrows by four species of armadillos in Brazil. J. Mammal. 64, 103-108.

Chiarello, A.G., 2000. Influência da caça ilegal sobre mamíferos e aves das matas de tabuleiro do norte do estado do Espírito Santo. Bol. Mus. Biol. Mello Leitão. 11, 229-247.

Cullen Jr., L., Bodmer, R.E., Pádua, C.V., 2000. Effects of hunting in habitat fragments of the Atlantic forests, Brazil. Biol. Conserv. 95, 49-56.
Cuéllar, E., Noss, A., 2004. Mamíferos del Chaco de Santa Cruz, Bolivia. Wildlife Conservation Society, Bolivia.

Dirzo, R., Miranda, A.M., 1990. Contemporary neotropical defaunation and forest structure, function and diversity - a sequel to John Terborgh. Conserv. Biol. 42, 444-447.

Eisenberg, J.F., Redford, K.H., 1999. Mammals from the Neotropics. The centra Neotropics: Ecuador, Peru, Bolivia, Brazil. University of Chicago Press, Chicago.

Emmons, L.H., 1990. Neotropical Rainforest Mammals. A Field Guide, 2nd ed. University of Chicago Press, Chicago.

Encarnação, C.D., (dissertation) 1987. Contribuição à ecologia dos tatus (Xernathra, Dasypodidae) da Serra da Canastra, Minas Gerais. National Museum, Federal University of Rio de Janeiro.

Ferreguetti, A.C., Tomas, W.M., Bergallo, H.G., 2015. Density, occupancy, and activity pattern of two sympatric deer (Mazama) in the Atlantic Forest, Brazil.J. Mammal. 96, 132-149, http://dx.doi.org/10.1093/jmammal/gyv132.

Fischer, W.A., (MS dissertation) 1997. Efeitos da BR-262 na mortalidade de vertebrados silvestres: síntese naturalista para a conservação da região do Pantanal. Federal University of Mato Grosso do Sul.

Gardner, A.L., 2007. Magnorder Xenarthra. In: Gardner, A.L. (Ed.), Mammals of South America. The University of Chicago Press, Chicago, pp. 127-176.

Glanz, W.E., 1996. The terrestrial mammal fauna of Barro Colorado Island: censuses and long-term changes. In: Leigh Jr., E.G., Rand, A.S., Windsor, D.M. (Eds.), The Ecology of a Tropical Forest: Seasonal Rhythms and Long-term Changes. Smithsonian Institution Press, Washington, pp. 455-466.

Hass, A., Rodrigues, F.H.G., Oliveira, T.G., 2003. The Yellow Armadillo, Euphractus sexcinctus, in the North/Northeastern Brazilian Coast. Edentata 5 46-47.

Hill, K., Padwe, J., Bejyvagi, C., Bepurangi, A., Jakugi, F., Tykuarangi, R., Tukuarangi, T. 1997. Monitoring hunting impact $n$ large vertebrates in the Mabaracayu reserve, Paraguay, using native research assistants. Conserv. Biol. 11, 1339-1353.

Instituto Brasileiro De Geografia (IBGE), 1993. Mapa de Vegetação do Brasil. Fundação Instituto Brasileiro de Geografia e Estatística, Rio de Janeiro.

Jesus, R.M., 1987. Mata Atlântica de Linhares: Aspectos Florestais. In: Sema, Iwrb, CVRD (Eds.), Desenvolvimento Econômico e Impacto Ambiental em Áreas de Trópico Úmido Brasileiro - A experiência da CVRD. CVRD, Rio de Janeiro, pp. 35-53.

Karanth, Nichols, K.U., Kumar, J.D., Link, N.S., Hines, W.A., 2004. Tigers and their prey: predicting carnivore densities from prey abundance. Proc. Natl. Acad. Sci. U. S. A. 101, 4854-4858.

Laake, J.L., Buckland, S.T., Anderson, D.R., Burnham, K.P., 1994. Distance User's Guide Colorado Cooperative Fish \& Wildlife Research Unit, Colorado State University, Fort Collins, CO.

Loughry, W.J., McDonough, C.M., 1997. Survey of the Xenarthrans inhabiting Poço das Antas Biological Reserve. Edentata 3, 5-7.

Loughry, W.J., McDonough, C.M., 1998. Comparisons between populations of ninebanded armadillos in Brazil and United States of America. Rev. Biol. Trop. 46, 1173-1183.

Loughry, W.J., McDonough, C.M., 2013. The Nine-Banded Armadillo: A Natural His tory. University of Oklahoma Press, Oklahoma.

Loughry, J., McDonough, C.M., Abba, A.M., 2014. Dasypus novemcinctus, The IUCN Red List of Threatened Species. Version 2014.3, www.iucnredlist.org (accessed 14.04.15).

Loughry, W.J., Superina, M., McDonough, C.M., Abba, A.M., 2015. Research on armadillos: a review and prospectus. J. Mammal., 1-10 (online published).

Lund, U., Agostinelli, C., 2007. Circular: Circular Statistics. R Package Version 0.3-8 http://CRAN.R-project.org/package5circular (accessed 05.09.14).

Mace, G.M., et al., 2000. It's time to work together and stop duplication of conservation efforts. Nature 405, 393.

MacKenzie, D.I., Royle, J.A., 2005. Designing occupancy studies: general advice and allocating survey effort. J. Appl. Ecol. 42, 1105-1114.

MacKenzie, D.I., Nichols, J., Royle, J., Pollock, K., Bailey, L., Hines, J., 2006. Occupancy Estimation and Modeling: Inferring Patterns and Dynamics of Species Occurrence. Elsevier Publishing.

Magnusson, W.E., Lima, A.P., Luizão, R., Luizão, F., Costa, F.R.C., De Castilho, C.V., Kinupp, V.P., 2005. RAPELD: a modification of the Gentry method for biodiversity surveys in long-term ecological research sites. Biota Neotrop. 5, 34-41.

McBee, K., Baker, R.J., 1982. Dasypus novemcinctus. Mamm. Species 162, 1-9.

McDonough, C.M., Loughry, W.J., 2008. Behavioral ecology of armadillos. In: Vizcaíno, S.F., Loughry, W.J. (Eds.), The Biology of the Xenarthra. University Press of Florida, pp. 281-293.

McDonough, C.M., Delaney, M., Le, P.Q., Blackmore, M.S., Loughry, W.J., 2000. Burrow characteristics and habitat associations of armadillos in Brazil and the United States of Americana. Rev. Biol. Trop. 48, 109-120.

Morris, D.W., 1987. Ecological scale and habitat use. Ecology 68, 362-369.

Nowak, R.M., 1999. Walker's Mammals of the World, 6th ed. The Johns Hopkins University Press, Baltimore/London.

Ojeda, R.A., Borghi, C.E., Roig, V.G., 2002. Mamíferos de Argentina. In: Ceballos, G. Simonetti, J.A. (Eds.), Diversidad y conservación de los mamíferos neotropicales. Conabio-UNAM, México, DF, pp. 23-63.

Paglia, A.P., et al., 2012. Annotated Checklist of Brazilian Mammals. Occasional Pape in Conservation Biology, 2nd ed. Conservation International, Arlington.

Peixoto, A.L., Gentry, A., 1990. Diversidade e composição florística da Mata de Tabuleiro na Reserva Florestal de Linhares (Espírito Santo, Brasil). Rev. Bras. Bot. 13, 19-25.

Peres, C.A., 1990. Effects of hunting on western Amazonian primate communities. Biol. Conserv. 54, 47-59. 
Peres, C.A., 2000. Effects of subsistence hunting on vertebrate community structure in Amazonian Forests. Conserv. Biol. 14, 240-253.

Powell, G., Leite, P.R., Tobler, M.W., Carrillo-Percastegui, S.E., Mares, R., 2008. An evaluation of camera traps for inventorying large- and medium-sized terrestrial rainforest mammals. Anim. Conserv. 11, 169-178.

R Development Core Team, 2008. R: A Language and Environment for Statistical Computing. R Foundation for Statistical Computing, Vienna, Austria, http:// www.R-project.org (accessed 15.10.14).

Redford, K.H., 1985. Food habits of armadillos (Xenarthra, Dasypodidae). In: Montgomery, G.G. (Ed.), The Evolution and Ecology of Armadillos, Sloths and Vermilinguas. Smithsonian Institution Press, Washington, DC, pp. 429-437.

Redford, K.H., 1992. The empty forest. Bioscience 42, 421-422.

Redford, K.H., Wetzel, R.M., 1985. Euphractus sexcinctus. Mamm. Species 252, 1-4.

Rosser, A.M., Mainka, S.A., 2002. Overexploitation and species extinctions. Conserv. Biol. 16, 584-586.

Sanches, R.A., 2001. Caiçara communities of the southeastern coast of São Paulo state (Brazil): Traditional activities and conservation policy for the Atlantic Rain Forest. Hum. Ecol. Rev. 8, 52-64.

Santos-Fita, D., Naranjo, E.J., Rangel-Salazar, J.L., 2012. Wildlife uses and hunting patterns in rural communities of the Yucatan Peninsula, Mexico. J. Ethnobiol. Ethnomed. 8, 01-17.

Schaller, G.B., 1983. Mammals and their biomass on a Brazilian ranch. Arq. Zool. 31, $1-36$.

Schoener, T.W., 1974. Resource partitioning. In: Kikkawa, J., Anderson, D.J. (Eds.), Community Ecology: Pattern and Processes. Blackwell, Palo Alto, CA, pp. 91-126.
Silva Junior, J.S., Fernandes, M.E.B., Cerqueira, R., 2001. New records of the yellow armadillo (Euphractus sexcinctus) in the state of Maranhão, Brazil (Xenarthra, Dasypodidae). Edentata 4, 18-23.

Souza, J.B., Alves, R.R., 2014. Hunting and wildlife use in an Atlantic Forest remnant of northeastern Brazil. Trop. Conserv. Sci. 7, 145-160.

Srbek-Araujo, A.C., (thesis) 2013. Conservação da onça-pintada (Panthera onca Linnaeus, 1758) na Mata Atlântica de tabuleiro do Espírito Santo. Universidade Federal de Minas Gerais, Belo Horizonte.

Superina, M., Pagnutti, N., Abba, A.M., 2014. What do we know about armadillos? An analysis of four centuries of knowledge about a group of South American mammals, with emphasis on their conservation. Mamm. Rev. 44,69-80.

Tabarelli, M., Mantovani, W., Peres, C.A., 1999. Effects of habitat fragmentation on plant guild structure in the montane Atlantic forest of southeastern Brazil. Biol. Conserv 91, 119-127.

Trolle, M., 2003. Mammal survey in the southeastern Pantanal, Brazil. Biodivers. Conserv. 12, 823-836.

Urquiza-Haas, T., Peres, C.A., Dolman, P.M., 2011. Large vertebrate responses to forest cover and hunting pressure in communal landholdings and protected areas of the Yucatan Peninsula, Mexico. Anim. Conserv. 14, 271-282.

Viera, E.M., 1996. Highway mortality of mammals in central Brazil. Cien. Cult. 48 270-272.

Wetzel, R.M., Gardner, A.L., Redford, K.H., 2007. Order Cingulata. In: Gardner, A.L. (Ed.), Mammals of South America, Volume 1: Marsupials, Xenarthrans, Shrews and Bats. The University of Chicago Press, Chicago, pp. 128-156. 